From the Department of Surgery, Royal Veterinary and Agricultural University, and National Institute of Animal Science, Copenhagen, Denmark.

\title{
Clinical Chemical Comparative Examination of Ruminal Samples Collected by Means of a Naso-Ruminal Sampler
}

By J. S. D. Poulsen, K. Özkan and J. O. Andersen

\begin{abstract}
Poulsen, J. S. D., K. Özkan and J. O. Andersen: Clinical chemical comparative examination of ruminal samples by means of a naso-ruminal sampler. Acta vet. scand. 1988, 29, 129-133. - Samples of ruminal fluid collected with the COMET naso-ruminal sampler and by two other methods through fistula were subjected to comparative clinical chemical examination. It was found that the mean values of $\mathrm{pH}$ and buffer capacity were nearly identical for all three methods. The greatest variation between the methods were found for reduction time of methylene blue owing to different dry matter contents in the samples. The VFA contents were nearly identical in all three samples.

In conclusion, it was found that it is possible to obtain ruminal samples that are representative of the biochemical status in the rumen by means of the COMET nasoruminal sampler in non-fistulated cows.
\end{abstract}

ruminal sampling; clinical chemical examination of ruminal juice.

\section{Introduction}

There is an increasing demand for examinations of ruminal fluid, in order to diagnose diseases of the digestive system as well as latent or subclinical conditions affecting the digestion and well-being of the animals.

The ruminal contents are very heterogeneous; and a sample representative of the biological and biochemical environment in the rumen is best collected under standard conditions, i.e. in relation to time of feeding (Smith et al. 1956) and location in the rumen (Monroe \& Perkins 1939, Smith 1941, Bryant 1964, Lampila \& Poutiainen 1966), preferably from the centre or ventral ruminal sac.

In the conventional methods of sampling ruminal fluid in non-fistulated cows, where a probe is introduced through the mouth or nose, the sample is mainly drawn from the dorso-cranial part of the rumen (Stöber \&
Tiefenbach 1958) where the coarse particles and a pool of saliva are usually found (Smith et al. 1956). Samples from this area will not be representative of the ruminal environment in relation to biochemical examination (Dirksen 1970, Behravesh 1984). It has, therefore, been the object of the present work to examine whether samples collected from the centre or ventral part of the ruminal sac with the COMET naso-ruminal sampler (Poulsen et al. 1986, 1988) are biochemically identical to samples obtained directly through a rumen fistula.

\section{Material and methods}

Ruminal samples collected with the naso-ruminal sampler and samples collected through a rumen fistula from a cow during a period of 3 weeks were subjected to clinical chemical tests.

Concomitant values of $\mathrm{pH}$, buffer capacity 
(BC), and reduction time of methylene blue were examined 14 times, while the concentrations of total and single volatile fatty acids (VFA) were examined 15 times. The samples were collected from the same area of the ruminal sac by 3 different methods concurrently, viz.:

1. Naso-ruminal sampler in situ (nose, pharynx, oesophagus, rumen) (Poulsen et al. 1988).

2. Sørensen-Schambye's sampler directly through a rumen fistula (no admixture of saliva).

3. Ruminal fluid expressed from ruminal material collected through a rumen fistula.

The sampling was done during the daytime. The $400 \mathrm{ml}$ samples were collected in thermojars. A vacuum pump (i.e. milking machine: $\mathbf{3 5 0 - 3 8 0 ~} \mathrm{mm} \mathrm{Hg}$ ) was used in connection with the naso-ruminal and SørensenSchambye's sampler. The ruminal fluid was examined for:

1. $\mathrm{pH}$, by means of a $\mathrm{pH}$-meter 27 (Radiometer).

2. Buffer capacity, measured by means of pH-meter 27, Titrator 11, ABU 1, and a glass (silver/silver chloride) (GK 2401), as well as a platinum electrode (P 101) (Radiometer). $1 \mathrm{ml}$ of $1.0 \mathrm{~N}$ sodium hydroxide was added to $20 \mathrm{ml}$ ruminal fluid before titration with $2-3 \mathrm{ml}$ of $1.0 \mathrm{~N}$ hydrochloric acid. The corresponding $\mathrm{pH}$ values and the amounts of acid added were measured and recorded in a diagram. The buffer capacity was calculated as the inclination of the tangent at the actual $\mathrm{pH}$ value of the ruminal fluid.

3. The reduction time of methylene blue was determined by carefully mixing (without shaking) $1 \mathrm{ml}$ of $0.03 \%$ methylene blue with $20 \mathrm{ml}$ ruminal fluid, incubation on water bath at $38^{\circ} \mathrm{C}$, and measuring the decoloration time in seconds.

\section{Volatile Fatty Acid}

1) Total amount. To $20 \mathrm{ml}$ of ruminal fluid was added $20 \mathrm{ml}$ acidic magnesium sulphate solution $\left(1 \mathrm{~kg} \mathrm{MgSO} 47 \mathrm{H}_{2} \mathrm{O}+1.51\right.$ of distilled water $+50 \mathrm{ml}$ conc. $\mathrm{H}_{2} \mathrm{SO}_{4}$ ). The mixture was centrifuged and $20 \mathrm{ml}$ of the supernatant liquid was employed for steam-destillation. $200 \mathrm{ml}$ destillate was collected and subsequently titrated with $0.1 \mathrm{~N} \mathrm{NaOH}$.

2) Percentage distribution. The titrated destillate from steam-destillation was evaporated to dryness. VFA was dissolved in $10 \mathrm{ml}$ diethyl ether by adding $0.5 \mathrm{ml} 4 \mathrm{~N}$ $\mathrm{HCl}$, and the water was removed by adding an exces of sodium sulphate drying agent. Separation of the individual VFA was accomplished by a Perkin-Elmer gaschromatograph model 900 with F.I.D.

\section{Statistical methods}

Differences between the methods were calculated and evaluated using a paired t-test. Ordinary correlation coefficients between the results of the 3 methods were evaluated.

\section{Results}

The mean values and standard deviations of the clinical chemical examination of duplicate samples (except for buffer capacity and VFA) are presented in Table 1.

The correlation coefficients between the 3 sampling methods are shown in Table 2.

\section{pH}

Statistical analysis showed no significant differences between the results obtained by using the three different methods of sampling ruminal fluid. However, the mean results of the Sørensen-Schambye method were higher and differed most from the other two. The difference is close to being statistically significant (Table 1). High and significant correlations were found between all 3 methods (Table 2). 
Table 1. Mean values and standard deviations of clinical chemical examination of ruminal samples obtained by 3 different methods.

\begin{tabular}{|c|c|c|c|c|c|c|c|}
\hline \multirow{2}{*}{$\begin{array}{l}\text { Sampling } \\
\text { methods }\end{array}$} & \multirow[t]{2}{*}{$\mathrm{pH}$} & \multirow{2}{*}{$\begin{array}{c}\text { Buffer capacity } \\
\text { eq } / \mathrm{pH} / \mathrm{kg}\end{array}$} & \multirow{2}{*}{$\begin{array}{l}\text { Methylene blue } \\
\text { reduction time } \\
\text { (s) }\end{array}$} & \multirow{2}{*}{$\begin{array}{c}\text { Total VFA } \\
\mathrm{mmol} / 1\end{array}$} & \multicolumn{3}{|c|}{ Percentage distribution of VFA } \\
\hline & & & & & $\begin{array}{l}\text { Acetic } \\
\text { acid }\end{array}$ & $\begin{array}{l}\text { Propionic } \\
\text { acid }\end{array}$ & $\begin{array}{c}\text { Butyric } \\
\text { acid }\end{array}$ \\
\hline $\begin{array}{l}\text { 1. Naso-Ruminal } \\
\text { Sampler }\end{array}$ & $\begin{array}{r}6,82 \\
\pm 0.30\end{array}$ & $\begin{array}{r}0.0254 \\
\pm 0.0021\end{array}$ & $\begin{array}{c}198.2 \\
\pm 87.15\end{array}$ & $\begin{array}{c}91.87 \\
\pm 15.684\end{array}$ & $\begin{array}{c}65.6 \\
\pm 1.32\end{array}$ & $\begin{array}{c}20.5 \\
\pm 1.18\end{array}$ & $\begin{array}{c}11.2 \\
\pm 0.39\end{array}$ \\
\hline $\begin{array}{l}\text { 2. Sørensen - } \\
\text { Schambye Sampler }\end{array}$ & $\begin{array}{r}7.08 \\
\pm 0.29\end{array}$ & $\begin{array}{r}0.0154 \\
\pm 0.0028\end{array}$ & $\begin{array}{c}152.9 \\
\pm 106.28\end{array}$ & $\begin{array}{c}93.67 \\
\pm 19.238\end{array}$ & $\begin{array}{c}65.4 \\
\pm 1.30\end{array}$ & $\begin{array}{c}20.7 \\
\pm 1.11\end{array}$ & $\begin{array}{r}11.2 \\
\pm 0.55\end{array}$ \\
\hline $\begin{array}{l}\text { 3. Fistula } \\
\text { by hand }\end{array}$ & $\begin{array}{r}6.72 \\
\pm 0.38\end{array}$ & $\begin{array}{r}0.0235 \\
\pm 0.0030\end{array}$ & $\begin{array}{c}63.6 \\
\pm 30.85\end{array}$ & $\begin{array}{c}99.73 \\
\pm 17.702\end{array}$ & $\begin{array}{c}65.6 \\
\pm 1.61\end{array}$ & $\begin{array}{c}20.5 \\
\pm 1.40\end{array}$ & $\begin{array}{c}11.1 \\
\pm 0.44\end{array}$ \\
\hline $\begin{array}{l}\text { Number of } \\
\text { examinations }\end{array}$ & 14 & 14 & 14 & 15 & 15 & 15 & 15 \\
\hline
\end{tabular}

Table 2. Correlation coefficients between three different ruminal sampling methods.

\begin{tabular}{|c|c|c|c|c|c|c|c|}
\hline \multirow{2}{*}{$\begin{array}{l}\text { Comparison between ru- } \\
\text { minal sampling methods } \\
\text { (Table 1) }\end{array}$} & \multirow[t]{2}{*}{$\mathrm{pH}$} & \multirow[t]{2}{*}{ Buffer capacity } & \multirow[t]{2}{*}{ Methylene blue } & \multirow[t]{2}{*}{ Total VFA } & \multicolumn{3}{|c|}{ Percentage distribution } \\
\hline & & & & & $\begin{array}{l}\text { Acetic } \\
\text { acid }\end{array}$ & $\begin{array}{l}\text { Propionic } \\
\text { acid }\end{array}$ & $\begin{array}{c}\text { Butyric } \\
\text { acid }\end{array}$ \\
\hline 1 and 2 & $0.84+++$ & 0.28 & $0.74++$ & $0.81++$ & $0.79++$ & $0.89+++$ & $0.66++$ \\
\hline 1 and 3 & $0.95+++$ & -0.33 & 0.36 & $0.81+++$ & $0.82+++$ & $0.93+++$ & 0.43 \\
\hline 2 and 3 & $0.83+++$ & 0.12 & 0.29 & $0.88+++$ & $0.85+++$ & $0.94+++$ & $0.75++$ \\
\hline $\overrightarrow{\operatorname{Prc}}$ & babilities 0 & f significance: & $\begin{array}{l}\text { Highly signific } \\
\text { Significant }(0 . \\
\text { Almost signifi }\end{array}$ & $\begin{array}{l}\text { ant }(p<0.00 \\
01<p<0.0 \\
\text { ant }(0.01<\end{array}$ & $\begin{array}{l}01+++) \\
01++) \\
p<0.05+)\end{array}$ & & \\
\hline
\end{tabular}

\section{Buffer capacity}

The mean values of the results obtained with the COMET naso-ruminal sampling method (1) and the fistula-sampling method (3) were nearly identical, whereas the mean value of the results obtained from the SørensenSchambye method was significantly lower than the results of the direct manual fistulasampling method. Correlations between the different methods were low.

\section{Reduction time of methylene blue}

The difference between the 3 sampling methods is not statistically significant. However, there is great variation between the mean values. Correlations between the me- thods are low, except between the naso-ruminal sampling method and the SørensenSchambye method (Table 2).

\section{Volatile fatty acids}

No statistically significant differences were found between the mean values of the 3 methods of collection. High and significant correlations were found between all 3 methods.

The internal percentage distribution of the single VFA (Table 1) showed no statistically significant differences, and the correlation coefficients between all 3 methods were highly significant, except for butyric acid. 


\section{Discussion}

Although the sampling times were not standardized in relation to feeding times, which caused a high degree of variation in the mean results (Tale 1), it was found that when related to the samples collected directly through fistula, the samples collected with the COMET apparatus were representative of the fermentative reactions in the ruminal contents as regards the parameters $\mathrm{pH}$, buffer capacity, and total as well as differentiated volatile fatty acids (Tables 1 and 2 ).

The differences between the samples collected by the Sørensen-Schambye method and those collected by the other methods might be due to the internal filter in the SørensenSchambye sampler head, which often gets clogged, resulting in interrupted and slow sampling with bubbling. Consequently, evaporation of carbonic dioxide will affect the results (higher $\mathrm{pH}$ ). Probably, the differences would be even greater if the SørensenSchambye sampler was introduced orally, because of the admixture of saliva (Dirksen 1970, Behravesh 1984).

A non-significant difference was found for the methylene blue test, which might be due to a lower dry matter content in the samples that were filtered through the suction units of the COMET naso-ruminal sampler and the Sørensen-Schambye sampler. The difference found in the reduction time of methylene blue was, however, in accordance with the observations of Behravesh (1984). He also found a longer reduction time in samples collected through a stomach tube applied orally than in samples collected manually through a fistula. On direct manual sampling through a fistula, Behravesh found a mean dry matter content of $3.15 \%$ and $3.17 \%$ in expressed rumen fluid, with methylene reduction times of 58 and $67 \mathrm{~s}$, respectively. In samples collected through stomach tube, the dry matter percentages were
2.23 and 2.28 , with reduction times of 80 and $93 \mathrm{~s}$, respectively. These findings demonstrate a certain correlation between the dry matter content of the samples and the methylene blue reduction time. The dry matter content was not measured in the present examination. It was obvious, however, that the filtering off of coarse particles by the COMET naso-ruminal sampler was very effective; no particles got into the samples. In case the COMET suction head gets clogged, a quick, forceful blow will clean it again.

With respect to VFA, correlation was high between the different sampling methods, except for butyric acid, and there was no statistically significant difference between the total and the single acids.

The examinations were performed in a cow with a normal fermentation pattern. Further investigation ought to be extended also to include cases of subclinical and clinical alkalosis and acidosis.

\section{Acknowledgement}

The authors wish to thank Drs. K. Christensen and H. H. Dietz for their generous help with the statistical work. Thanks are also due to Mrs. M. Johansen for technical assistance, and to Mrs. Alice Jensen, Development Cooperation Bureau for revising the English text.

\section{References}

Behravesh S: Examination of the ruminal fluid and blood of bovines fed different diets. A biochemical, clinical chemical, microbiological and physical study. Ph. D. thesis, Department of Surgery, Royal Vet. and Agricultural University, Copenhagen, Denmark.

Bryant A M: Variations in the $\mathrm{pH}$ and volatile fatty acid concentration within the bovine reticulo-rumen. N. Z. J. agric. Res., 1964, 7, 694-706.

Dirksen G: Acidosis. In: Physiology of Digestion and Metabolism in the Ruminant. Edited by $\mathbf{A}$. T. Phillipson. Oriel Press, Newcastle upon Tyne, 1970 , p. $350-361$. 
Lampila $M$, Poutiainen E: Systemic differences in the composition of the bovine rumen fluid between different parts of the rumen. Ann. Agric. Fenn. 1966, 5, 279-297.

Monroe C F, Perkins A E: A study of the $\mathrm{pH}$ values of the ingesta of the bovine rumen. J. Dairy Sci. 1939, 22, 983-991.

Poulsen JS D, Özkan K, Hekmati P: The Comet Naso-Ruminal Sampler. An examination of a new instrument for continuous collection of ruminal fluid during long experimental periods. Proceedings. Sixth International Conference on Production Disease in Farm Animals. Belfast, Northern Ireland, 1986.

Poulsen J S D, Olesen F, Hekmati P, Bakshodeh G A: Technical evaluation of a naso-ruminal instrument for collection of ruminal samples. Acta vet. scand. 1988, 29, 135-137.

Smith VR: In vivo studies of hydrogen ion concentrations in the rumen of the dairy cow. J. Dairy Sci. 1941, 24, 659-665.

Smith $P H$, Sweeney $H C$, Rooney $J R$, King $K W$, Moore $W E$ : Statifications and kinetic changes in the ingesta of the bovine rumen. J. Dairy Sci. 1956, 39, 598-609.
Stöber M, Tiefenbach B: Pansensaftgewinnung und Vormagenentleerung $\mathrm{zu}$ therapeutischen Zwecken-Prüfung der Brauchbarkeit von drei Instrumenten. (Rumen juice collection and emptying of proventriculi for therapeutical purpose - an examination of the use of 3 instruments). Dt. tierärztl. Wschr. 1958, 65, 11-16.

\section{Sammendrag}

En sammenlignende klinisk kemisk undersogelse af vomprover opsamlet ved hjoelp af "Naso-Ruminal Sampler«.

Ved en sammenlignende klinisk kemisk undersøgelse af vomsaftprøver opsamlet gennem dels vomfistel (2 metoder) og dels ved Comet Naso-Ruminal Prøveopsamler fandtes næsten identiske resultater for $\mathrm{pH}$, bufferkapacitet og indhold af flygtige fede syrer. Den største variation mellem opsamlingsmetoderne fandtes for reduktionstiden for metylenblăt, sandsynligvis som følge af forskelle i prøvernes tørstofkoncentration.

Det konkluderes, at det ved hjælp af Comet NasoRuminal Prøveopsamler er muligt at opsamle enkelte sável som serier af vomsaftprøver (dage, uger), som er repræsentative for den biokemiske status i vommen.

(Received July 3, 1987).

Reprints may be requested from: J. S. Dirch Poulsen, Clinical Central Laboratory, Royal Veterinary and Agricultural University, Bülowsvej 13, DK-1870 Frederiksberg C., Denmark. 
